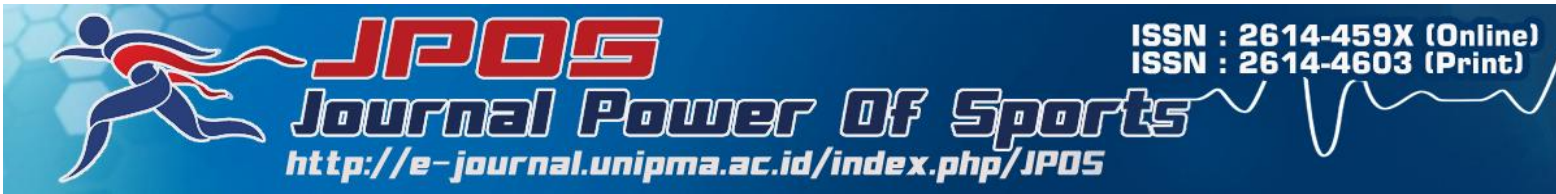

\title{
Perkembangan kemampuan fisik (kelentukan, kekuatan otot ekstensor, dan kelincahan) orang dewasa muda ditinjau dari usia dan etnik
}

\author{
Junalia Muhammad \\ Fakultas Ilmu Keolahragaan, Universitas Cenderawasih, Papua, Indonesia \\ Email: junaliamuhammad@ymail.com
}

Received: 14 Februari 2018. Accepted: 8 Agustus 2018. Published: 31 Agustus 2018

\begin{abstract}
Abstrak
Penelitian ini bertujuan untuk mengetahui a) perbandingan kelentukan orang dewasa muda asli Papua dan non Papua pada usia 20 - 23 tahun, b) perbandingan kekuatan otot ekstensor orang dewasa muda asli Papua dan non Papua pada usia 20 - 23 tahun, dan c) perbandingan kelincahan orang dewasa muda asli Papua dan non Papua pada usia $20-23$ tahun. Sifat kesukuan merupakan faktor keturunan dari orang tua yang kemudian berkembang melalui interaksi yang kompleks dengan berbagai faktor lingkungan. Beragam faktor lingkungan yang ada dalam kehidupan berbagai suku bangsa, mengakibatkan terjadinya perbedaan ukuran tubuh rata-rata orang dewasa, kecepatan pertumbuhan, kemampuan fisik dan bentuk tubuh antara kelompok suku-suku bangsa yang berbeda. Pada proses penelitian ini, akan digunakan beberapa teori mendasarkan yang dijadikan pijakan dalam menganalisis data penelitian ini. Teori-teori tersebut antara lain: Perkembangan gerak, kemampuan fisik, kelentukan, kekuatan, dan kelincahan. Penelitian ini menggunakan metode penelitian cross sectional memungkinkan peneliti untuk mengumpulkan data pada berbagai kelompok orang dengan tingkat usia yang bervariasi pada kurun waktu yang sama. Subyek yang digunakan dalam penelitian ini adalah mahasiswa FIK UNCEN (Fakultas Ilmu Keolahragaan Universitas Cendrawasih) yang berjumlah 40. Instrumen penelitian terdiri dari 1) sit and reach untuk mengukur kelentukan, 2) standing broad jump untuk mengukur kekuatan otot ekstensor dan 3) shuttle run untuk mengukur kelincahan. Analisis yang digunakan dalam penelitian ini adalah analisis interaktif. Dari angka-angka yang dihasilkan dalam analisis data menunjukkan bahwa, Perbandingan perkembangan kemampuan fisik orang dewasa muda usia 20-23 tahun asli Papua memiliki kelentukan lebih rendah (35\%) dibandingkan dengan non Papua (45\%) pada mahasiswa FIK UNCEN (Fakultas Ilmu Keolahragaan Universitas Cendrawasih). Perbandingan perkembangan kemampuan fisik orang dewasa muda usia 20-23 tahun asli Papua memiliki kekuatan otot ekstensor lebih rendah (42.5\%) dibandingkan dengan non Papua (45\%) pada mahasiswa FIK UNCEN (Fakultas Ilmu Keolahragaan Universitas Cendrawasih). Perbandingan perkembangan kemampuan fisik orang dewasa muda usia 20-23 tahun asli Papua memiliki kelentukan lebih tinggi (100\%) dibandingkan dengan non Papua (92.5\%) pada mahasiswa FIK UNCEN (Fakultas Ilmu Keolahragaan Universitas Cendrawasih).
\end{abstract}

Kata Kunci: perkembangan; kemampuan fisik; dewasa muda; usia; etnik. 
Developing of physical strength (flexibility, extensor muscle strength, and agility) of young adult viewed from age and ethnic

\begin{abstract}
The ethnically characteristic is hereditary factor from oldster which developing to interaction complex with environment factors various. Many environment factors in life of many ethnic, made difference of adult average body sizes, growth speed, body form and physic ability between different ethnics group. This research aims to find a) flexibility comparison of Papuan and non Papuan ethnic young adult at 20-23 years old, b) extensor muscles power comparison of Papuan and non Papuan ethnic young adult at 20-23 years old, c) agility comparison of Papuan and non Papuan ethnic young adult at 20-23 years old. The theories in this research are : moving development, physical power, flexibility, power, and agility. This research used cross-sectional research method that is may the researcher collectiong data of various people groups with variety age level on same time. The subjects used 40 college students from FIK UNCEN (Fakultas Ilmu Keolahragaan Universitas Cendrawasih). The research instruments there are 1) sit and reach toa measure flexibility, 2) standing broad jump to measure extensor muscle strong, and 3) shuttle run to measure agility. The data analysis uses interactive analysis. The results of this research shows the comparison of physical power development of Papuan ethnic young adult at 20-23 years old had lowest flexibility (35\%) as compared to non Papuan ethnic (45\%). The comparison of physical power development of Papuan ethnic young adult at 20-23 years old had lowest extensor muscle strength (42,5\%) as compared to non Papuan (45\%). The comparison of physical power development of Papuan ethnic young adult at 20-23 years old had highest (100\%) as compared to non Papuan (92,5\%).
\end{abstract}

Key Words: developing; physical strength; young adult; agility; age; and ethnic.

How To Cite : Muhammad, J. (2018). Perkembangan kemampuan fisik (kelentukan, to APA Style kekuatan otot ekstensor, dan kelincahan) orang dewasa muda ditinjau dari usia dan etnik. JPOS (Journal Power Of Sports), 1 (2), 1-7.

\section{PENDAHULUAN}

Peningkatan kemampuan fisik masa dewasa bukan lagi merupakan peningkatan yang dihasilkan proses oleh pertumbuhan yang menyertai bertambahnya usia, tetapi merupakan hasil dari pengalaman dan latihan. Umur puncak kecepatan terjadi pada umur 20 tahun, kekuatan ada pada umur 30 tahun, dan daya tahan berlangsung pada umur sekitar 40 tahunan. Penyimpangan dari dari konsep tersebut dapat terjadi karena faktor biologis atau latihan-latihan yang dilakukan (Sugiyanto, dkk, 1998: 210).

Kemampuan fisik adalah kemampuan tugas-tugas yang menuntut stamina, keterampilan, kekuatan, dan karakteristik serupa. Kondisi fisik adalah satu kesatuan utuh dari komponenkomponen yang tidak dapat dipisahkan baik peningkatannya maupun pemeliharaannya. Artinya bahwa setiap usaha peningkatan kondisi fisik maka harus mengembangkan semua komponen tersebut. Walaupun dilakukan dengan sistem prioritas (komponen apa yang perlu mendapat porsi latihan lebih besar dibanding komponen lain). Sesuai status yang diketahui setiap komponen tersebut diukur dan dinilai (Sajoto, 1988: 57).

Komponen-komponen kondisi fisik dapat dikemukakan sebagai berikut: 1) kekuatan (strenght), 2) daya tahan (endurance) (daya tahan otot dan daya tahan umum), 3) daya ledak otot (muscular 
power), 4) kecepatan (speed), 5) kelentukan (fleksibility), 6) keseimbangan (balance), 7) koordinasi (coordination), 8) kelincahan (agility), 9) ketepatan (accuracy), dan 10) reaksi (reaction) (Sajoto, 1988: 58).

$\begin{array}{ccc}\text { Pada } & \text { penelitian sebelumnya telah } \\ \text { dibahas } & \text { tentang } & \text { perkembangan }\end{array}$ kemampuan fisik daya tahan otot lengan dan bahu, daya tahan otot perut, dan daya tahan kardiovaskuler pada orang dewasa muda ditinjau dari jenis kelamin. Dimana hasil penelitian tersebut, bahwa perkembangan kemampuan fisik daya tahan otot lengan dan bahu dan daya tahan otot perut pada orang dewasa muda lakilaki usia 20-23 tahun masih memiliki perkembangan yang konsisten, sedangkan pada ketahanan kardiovaskuler hampir mengalami penurunan.

Sedangkan perkembangan kemampuan fisik daya tahan otot lengan dan bahu pada orang dewasa muda perempuan usia 20-23 tahun hampir mengalami penurunan, sedangkan perkembangan daya tahan otot perut masih memiliki perkembangan yang konsisten, dan perkembangan ketahanan kardiovaskuler sangat mengalami penurunan ( Junalia dan Mifta, 2016: 5).

Komponen-komponen kebugaran fisik/aktivitas fisik yang dapat membantu mengurangi kemungkinan terjadinya penyakit-penyakit degeneratif, penyakit jantung coroner, obesitas, dan kelemahan dari sendi dan otot memerlukan suatu tingkat yang cukup dari kebugaran kesehatan maupun performance. Kebugaran kesehatan terdiri dari kebugaran jantung-paru-peredaran darah, lemak tubuh, kekuatan otot, dan kelenturan sendi, sedangkan kebugaran performance terdiri dari ketahanan otot, tenaga otot, ketangkasan, kelincahan, dan kecepatan (Giam, 1992:9).

Fleksibilitas sendi adalah kemampuan dari berbagai sendi tubuh untuk bergerak pada jarak maksimal mereka. Ada dua tipe fleksibilitas: statis dan dinamis. Fleksibilitas statis adalah gerakan yang dilakukan dengan pelanpelan dan tarikan yang lambat dengan keterlibatan sendi yang sangat terbatas. Fleksibilitas dinamis adalah gerakan yang dilakukan dengan cepat hingga mencapai batasnya (Williams, 1993).

Kekuatan otot adalah kemampuan otot atau kelompok otot untuk melakukan kerja, dengan menahan beban yang diangkatnya. Otot yang kuat akan membuat kerja otot sehari-hari secara efisien seperti, mengangkat, menjinjing, lompat, loncat serta mereka akan membuat bentuk tubuh yang lebih baik (Sajoto, 1988 :45).

Kelincahan atau agility adalah kemampuan seseorang dalam merubah arah, dalam posisi-posisi di arena tertentu. Seorang yang mampu merubah satu posisi ke suatu posisi yang berbeda, dengan kecepatan tinggi, dan koordinasi gerak yang baik, berarti kelincahannya cukup tinggi (Sajoto Mochamad, 1995: 9).

Dari hasil penelitian yang membandingkan kemmpuan fisik pelajar dan mahasiswa diketahui bahwa wanita pada usia mahasiswa mengalami penurunan power pada otot-otot lengan, sedangkan pada laki-laki usia mahasiswa justru mengalami peningkatan. Perbandingan keadaan fisik antara pria dan wanita dewasa menunjukkan bahwa wanita memiliki tubuh yang relatif lebih kecil. Proporsi jaringan lemak dengan otot berbanding 18:35 utuk wanita, sedangkan pria 18:42.

Dengan perbandingan tersebut pria lebih untung ditinjau dari segi kemampuan gerak. Dibandingkan dengan pria, wanita kurang memiliki skeletal yang kokoh, sehingga kurang menunjang kekuatan. Sedangkan kelemahan pada beberapa persendian terutama kurang kuatnya kapsul sendi dapat berakibat terbatasnya gerakan (Gallahue dan Ozmun, 1998).

Sifat kesukuan merupakan faktor keturunan dari orang tua yang kemudian berkembang melalui interaksi yang kompleks dengan berbagai faktor lingkungan. Beragam faktor lingkungan 
yang ada dalam kehidupan berbagai suku bangsa, mengakibatkan terjadinya perbedaan ukuran tubuh rata-rata orang dewasa, kecepatan pertumbuhan, kemampuan fisik dan bentuk tubuh antara kelompok suku-suku bangsa yang berbeda. Bangsa Indonesia yang terdiri dari berbagai suku bangsa, bisa diamati juga ada perbedaan bentuk tubuh antara sukusuku tertentu.

Walaupun belum ada penelitian tentang hal ini, namun agak mudah untuk membedakan tipe bentuk tubuh misalnya suku Jawa, suku Irian, atau suku Ambon. Perbedaan yang paling jelas paling tidak adalah bentuk wajahnya (Sugiyanto, 1998).

Berdasarkan latar belakang di atas maka perlu dilakukan penelitian mengenai "Perkembangan kemampuan fisik (kelentukan, kekuatan otot ekstensor, dan kelincahan) orang dewasa muda ditinjau dari usia dan etnik."

Dengan demikian, maka dapat dirumuskan permasalahan dalam penelitian ini sebagai berikut: a.) Bagaimanakah perbandingan kelentukan orang dewasa muda asli Papua dan non Papua pada usia 20 - 23 tahun?; b.) Bagaimanakah perbandingan kekuatan otot ekstensor orang dewasa muda asli Papua dan non Papua pada usia 20 - 23 tahun?; c.) Bagaimanakah perbandingan kelincahan orang dewasa muda asli Papua dan non Papua pada usia 20 - 23 tahun?

\section{METODE PENELITIAN}

Berdasarkan masalah yang diajukan dalam penelitian ini, maka bentuk penelitian ini adalah penelitian kualitatif. Jenis penelitian ini akan mampu menangkap sebagai informasi kualitatif dengan deskripsi teliti, yang lebih berharga daripada sekedar pernyataan jumlah ataupun frekuensi dalam bentuk angka.
Penelitian kualitatif menurut definisi adalah penelitian yang dimaksudkan untuk memahami fenomena tentang apa yang dialami oleh subyek penelitian misalnya perilaku, motivasi, tindakan, dan lain-lain, secara holistik dengan cara deskripsi dalam bentuk kata-kata dan bahasa, pada suatu konteks khusus yang alamiah dan dengan memanfaatkan sebagai metode alamiah (Dantes, 2012: 49).

Subyek yang digunakan dalam penelitian ini adalah mahasiswa FIK UNCEN (Fakultas Ilmu Keolahragaan Universitas Cendrawasih) berusia 20-23 tahun yang berjumlah 40 orang terdiri dari 20 orang asli Papua dan 20 orang non Papua.

Metode penelitian cross-sectional memungkinkan peneliti untuk mengumpulkan data pada berbagai kelompok orang dengan tingkat usia yang bervariasi pada kurun waktu yang sama.

Tujuan utama dari penelitian crosssectional adalah untuk mengukur perbedaan dalam perilaku (Gallahue dan Ozmun, 1998: 8).

Analisis yang digunakan dalam penelitian ini adalah analisis interaktif. Analisis interaktif yaitu suatu analisis data kualitatif yang terdiri dari: (1) reduksi data, (2) kategorisasi, (3) sintesisasi dan (4) penarikan kesimpulan/verifikasi. Analisis data yang dilakukan secara bersamaan (Moleong, 2013: 288).

\section{HASIL DAN PEMBAHASAN}

Secara lengkap di bawah ini akan disajikan perkembangan kemampuan fisik kelentukan, kekuatan otot ekstensor dan kelincahan orang dewasa muda asli Papua dan non Papua usia 20 sampai dengan 23 tahun pada mahasiswa FIK UNCEN (Fakultas Ilmu Keolahragaan Universitas Cendrawasih) dalam bentuk tabel hasil persentase sebagai berikut: 
JPOS (Journal Power Of Sports), 1 (2) 2018, (1-7)

Tabel 1. Jumlah Persentase Perkembangan Kemampuan Fisik Sesuai Dengan Kategori Pada Orang Dewasa Muda Usia 20 Sampai Dengan 23 Tahun Asli Papua.

\begin{tabular}{ccccccc}
\hline \multirow{2}{*}{ Kategori } & \multicolumn{6}{c}{ Kemampuan Fisik Asli Papua } \\
\cline { 2 - 7 } & \multicolumn{2}{c}{ Kelentukan } & \multicolumn{2}{c}{$\begin{array}{c}\text { Kekuatan Otot } \\
\text { Ekstensor }\end{array}$} & \multicolumn{2}{c}{ Kelincahan } \\
\cline { 2 - 7 } & Jumlah & $\mathbf{\%}$ & Jumlah & $\mathbf{\%}$ & Jumlah & \% \\
\hline Baik Sekali & 2 & 10 & 3 & 15 & 16 & 80 \\
\hline Baik & 4 & 20 & 5 & 25 & 4 & 20 \\
\hline Cukup & 2 & 10 & 1 & 5 & 0 & 0 \\
\hline Kurang & 6 & 30 & 6 & 30 & 0 & 0 \\
\hline Kurang Sekali & 6 & 30 & 5 & 25 & 0 & 0 \\
\hline Jumlah & $\mathbf{2 0}$ & $\mathbf{1 0 0}$ & $\mathbf{2 0}$ & $\mathbf{1 0 0}$ & $\mathbf{2 0}$ & $\mathbf{1 0 0}$ \\
\hline
\end{tabular}

Tabel 2. Jumlah Persentase Perkembangan Kemampuan Fisik Sesuai Dengan Kategori Pada Orang Dewasa Muda Usia 20 Sampai Dengan 23 Tahun Non Papua.

\begin{tabular}{ccccccc}
\hline \multirow{3}{*}{ Kategori } & \multicolumn{6}{c}{ Kemampuan Fisik Non Papua } \\
\cline { 2 - 7 } & \multicolumn{2}{c}{ Kelentukan } & \multicolumn{2}{c}{$\begin{array}{c}\text { Kekuatan Otot } \\
\text { Ekstensor }\end{array}$} & \multicolumn{2}{c}{ Kelincahan } \\
\cline { 2 - 7 } & Jumlah & $\mathbf{\%}$ & Jumlah & $\mathbf{\%}$ & Jumlah & \% \\
\hline Baik Sekali & 7 & 35 & 1 & 5 & 6 & 30 \\
\hline Baik & 1 & 5 & 6 & 30 & 11 & 55 \\
\hline Cukup & 2 & 10 & 4 & 20 & 3 & 15 \\
\hline Kurang & 3 & 15 & 2 & 10 & 0 & 0 \\
\hline Kurang Sekali & 6 & 30 & 7 & 35 & 0 & 0 \\
\hline Jumlah & $\mathbf{2 0}$ & $\mathbf{1 0 0}$ & $\mathbf{2 0}$ & $\mathbf{1 0 0}$ & $\mathbf{2 0}$ & $\mathbf{1 0 0}$ \\
\hline
\end{tabular}

Dari tabel 1 di atas menunjukkan bahwa, perkembangan orang dewasa muda usia 20-23 tahun asli Papua pada mahasiswa FIK UNCEN (Fakultas Ilmu Keolahragaan Universitas Cendrawasih) yang memiliki kelentukan kategori baik sekali berjumlah 2 orang (10\%), kategori baik berjumlah 4 orang (20\%), kategori cukup berjumlah 2 orang (10\%) masingmasing berjumlah 19 orang (17.3\%), dan kategori kurang dan kurang sekali masingmasing berjumlah 6 orang $(30 \%)$. Pada kekuatan otot ekstensor yang memiliki kategori baik sekali berjumlah 3 (15\%), kategori baik 5 orang (25\%), kategori cukup 1 orang (5\%), kategori kurang 6 orang (30\%), dan kategori kurang sekali 5 orang $(25 \%)$. Sedangkan pada kelincahan yang memiliki kategori baik sekali berjumlah 16 (80\%), kategori baik 4 orang
(20\%), kategori cukup, kurang dan kurang sekali masing-masing berjumlah $0 \%$.

Kemudian dari table 2 di atas menunjukkan bahwa, perkembangan orang dewasa muda usia 20-23 tahun non Papua pada mahasiswa FIK UNCEN (Fakultas Ilmu Keolahragaan Universitas Cendrawasih) yang memiliki kelentukan kategori baik sekali berjumlah 7 orang (35\%), kategori baik berjumlah 1 orang (5\%), kategori cukup 2 orang (10\%), kategori kurang 3 orang (15\%), dan kategori kurang sekali 6 orang (30\%).

Pada kekuatan otot ekstensor yang memiliki kategori baik sekali berjumlah 1 (5\%), kategori baik 6 orang (30\%), kategori cukup 4 orang (20\%), kategori kurang 2 orang (10\%), dan kategori kurang sekali 7 orang $(35 \%)$. Sedangkan pada kelincahan yang memiliki kategori baik sekali berjumlah 6 (30\%), kategori baik, 
11 orang $(55 \%)$, kategori cukup 3 orang (15\%), dan kategori kurang dan kurang sekali berjumlah $0 \%$.

Dari hasil analisis data menunjukkan bahwa, perkembangan kemampuan fisik kelincahan orang dewasa muda usia 20-23 asli Papua pada mahasiswa FIK UNCEN (Fakultas Ilmu Keolahragaan Universitas Cendrawasih) masih memiliki perkembangan yang konsisten, sedangkan pada kelentukan perkembangannya mengalami penurunan, dan pada kekuatan otot ekstensor hamper mengalami penurunan.

Sedangkan dari hasil analisis data orang dewasa muda usia 20-23 tahun non Papua pada mahasiswa FIK UNCEN (Fakultas Ilmu Keolahragaan Universitas Cendrawasih) menunjukkan bahwa, perkembangan kemampuan fisik kelincahan orang dewasa muda usia 20-23 tahun non Papua pada mahasiswa FIK UNCEN (Fakultas Ilmu Keolahragaan Universitas Cendrawasih) memiliki perkembangan yang konsisten, sedangkan kekuatan otot ekstensor kelentukan orang dewasa muda usia 20-23 tahun non Papua pada mahasiswa FIK UNCEN (Fakultas Ilmu Keolahragaan Universitas Cendrawasih) memiliki perkembangan hampir mengalami penurunan.

Perbandingan perkembangan kemampuan fisik orang dewasa muda usia 20-23 tahun asli Papua memiliki kelentukan lebih rendah (35\%) dibandingkan dengan non Papua (45\%) pada mahasiswa FIK UNCEN (Fakultas Ilmu Keolahragaan Universitas Cendrawasih).

Perbandingan perkembangan kemampuan fisik orang dewasa muda usia 20-23 tahun asli Papua memiliki kekuatan otot ekstensor lebih rendah $(42.5 \%)$ dibandingkan dengan non Papua (45\%) pada mahasiswa FIK UNCEN (Fakultas Ilmu Keolahragaan Universitas Cendrawasih). Sedangkan perbandingan perkembangan kemampuan fisik orang dewasa muda usia 20-23 tahun asli Papua memiliki kelentukan lebih tinggi (100\%) dibandingkan dengan non Papua $(92.5 \%)$ pada mahasiswa FIK UNCEN (Fakultas Ilmu Keolahragaan Universitas Cendrawasih).

\section{KESIMPULAN}

1. Perbandingan perkembangan kemampuan fisik orang dewasa muda usia 20-23 tahun asli Papua memiliki kelentukan lebih rendah (35\%) dibandingkan dengan non Papua (45\%) pada mahasiswa FIK UNCEN (Fakultas Ilmu Keolahragaan Universitas Cendrawasih).

2. Perbandingan perkembangan kemampuan fisik orang dewasa muda usia 20-23 tahun asli Papua memiliki kekuatan otot ekstensor lebih rendah (42.5\%) dibandingkan dengan non Papua (45\%) pada mahasiswa FIK UNCEN (Fakultas Ilmu Keolahragaan Universitas Cendrawasih).

3. Perbandingan perkembangan kemampuan fisik orang dewasa muda usia 20-23 tahun asli Papua memiliki kelentukan lebih tinggi (100\%) dibandingkan dengan non Papua (92.5\%) pada mahasiswa FIK UNCEN (Fakultas Ilmu Keolahragaan Universitas Cendrawasih).

\section{DAFTAR PUSTAKA}

Gallahue., David, L., \& John, O. C. (1998). Understanding Motor Development; Infants, Children, Adolescents, Adults $4^{\text {th }}$ Edition. New York: Mc Graw-Hill Companies, Inc.

Giam, C. K., Teh, K. C. (1992). Sport Medicine, Exercise and Fitness. Singapore: PG Publishing.

Junalia, M. (2016). Perkembangan Kemampuan Fisik Orang Dewasa Muda Ditinjau dari Usia dan Jenis Kelamin. Universitas Cenderawasih 
JPOS (Journal Power Of Sports), 1 (2) 2018, (1-7)

Moleong., Lexy, J. (2013). Metodologi

Penelitian Kualitatif. Bandung: $\mathrm{Pt}$

Remaja Rosdakarya.

Sajoto, M. (1995). Peningkatan dan

Pembinaan Kekuatan Kondisi Fisik

dalam Olahraga. Semarang :

Dahara Prize.

Sajoto, M. (1988). Pembinaan Kondisi Fisik Dalam Olahraga. Housten.

Sugiyanto. (1998). Perkembangan dan

Belajar Motorik. Jakarta:

Departemen Pendidikan dan

Kebudayaan.

Williams, I. (1993). Lifetime Fitness and Wellness: A Personal Choice.

Dubuque, IA: Brown and

Benchmark. 